\title{
Temporal patterns control carbon balance in forest and agricultural tropical peatlands in North Selangor, Malaysia
}

\author{
Jeyanny Vijayanathan (1), \\ Mohammad Fakhri Ishak ${ }^{(1)}$, \\ Ismail Parlan ${ }^{(1)}$, \\ Hamdan Omar ${ }^{(1)}$, \\ Ahmed Osumanu Haruna ${ }^{(2-3)}$, \\ Marryanna Lion ${ }^{(1)}$, \\ Mohd Ghazali Hassan (1), \\ Regina Mariah Jong ${ }^{(4)}$, \\ Abdul Khalim Abu Samah ${ }^{(4)}$
}

\begin{abstract}
Tropical peat swamp forests can sequester significant amount of carbon (C). However, there is dearth of understanding on the tropical soils' C stocks and emissions because of the changes in peatland use, land use policies, and micro-climate. The objective of this study was to determine the $C$ stocks and fluxes of two peat swamp forests and a peatland under mixed cropping in Selangor, Malaysia. Standard procedures were used to determine aboveground biomass, belowground biomass, selected peat soil physical, chemical, and biological properties, and environmental variables that are related to peat soil respirations. The mean $\mathrm{C}$ stocks for the peat swamp forest and mixed cropping sites were $1788.79 \mathrm{MgC} \mathrm{ha}^{-1}$ and $1023.57 \mathrm{MgC} \mathrm{ha}^{-1}$, respectively. The carbon dioxide emission rates of peat swamp forest and mixed cropping sites ranged from 7.20 to $73.13 \mathrm{tCO}_{2} \mathrm{ha}^{-1}$ year $^{-1}$ and 26.50 to $43.43 \mathrm{tCO}_{2} \mathrm{ha}^{-1}$ year $^{-1}$, respectively. These emissions are related to seasonal changes because the relative humidity, soil temperature, and ground water of the experimental sites had significant effects on soil respiration. Unlike the mixed cropping sites, the fluxes of the peat swamp forest were significantly higher in the dry season compared with the wet season. These findings suggest that peat soil respiration is controlled by relative humidity, temperature, and the changes in ground water table. Continued monitoring and conservation efforts to preserve stored $C$ in peatlands are essential.
\end{abstract}

Keywords: Peat Characteristics, Carbon Storage, Carbon Dioxide Fluxes, Cash Crop Cultivation, Seasonal Variations

(Page et al. 2011, Dargie et al. 2017). However, if they are not carefully managed, they can be a source of carbon dioxide $\left(\mathrm{CO}_{2}\right)$ and methane $\left(\mathrm{CH}_{4}\right)$. The occurrence of peatlands in Malaysia is approximately 2.6 $\mathrm{M} \mathrm{ha}^{-1}$ (Melling 2016) out of which approximately $0.64 \mathrm{M}^{-1}$ occurs in the Peninsular Malaysia (Parish et al. 2008). The ever-increasing demands for agricultural and wood product lands has been implicated in the on-going soil C loss, climate change, forest degradation, bush fires, among others (Manning et al. 2019, Cooper et al. 2020, Hooijer et al. 2010). Peatlands also play an important role in food security. For example, edible oils from the oil palm cultivation on peat soil have been sustaining the economies of many countries (Murphy 2014, Vijay et al. 2016). Planting cash crops such as soybean, maize, and cassava on peat soils reduces malnutrition, hunger, poverty, and unemployment (Abdullah et al. 2012). However, the improper management of peatlands for food production has been implicated in in the on-going environmental quality degradation. The literature is replete with information on greenhouse gas (GHG) emissions, particularly $\mathrm{CO}_{2}$ emission from oil palm cultivation on tropical peat soils that had been estimated ranging from 19 to $94 \mathrm{t} \mathrm{CO}_{2}$ year-1 (Melling et al. 2005, Manning et al. 2019, Cooper et al. 2020). Unlike the oil palm industry, there is limited information on the $\mathrm{CO}_{2}$ emission from other cash crops cultivated on peat soils suggesting that that the $\mathrm{CO}_{2}$ emission for the cultivation of pineapples and sago in the eastern part of Malaysia (Borneo) ranges from 12.55 to $179.6 \mathrm{t} \mathrm{CO}_{2}$ ha $^{-1}$ year ${ }^{-1}$ (Melling et al. 2005, Choo \& Ahmed 2014). Information of this kind is lacking for the western part of Malaysia (Peninsular Malaysia) where peat soils are often cultivated with cash crops such as pineapples, banana, and cassava.

Information on climate heterogeneity such as relative humidity, rainfall, water table, soil and air temperatures (Melling et al. 2005, Ishikura et al. 2017, Ishikura et al. 2018) with monsoonal transitions and the impact of the controlling factors on soil respiration are still scarce. Understanding these factors and their confounding effects on soil $\mathrm{CO}_{2}$ fluxes may serve as a guideline for refining integrated management plans for peatlands.

The first objective of this study was to explain the temporal variations in soil $\mathrm{CO}_{2}$ fluxes due to seasonal change caused by changes in environmental and anthropogenic factors such as rainfall, air temperature, relative humidity, water table and land use. The second objective of this study was to determine selected peatland properties and $C$ stocks under two contrasting land uses for sustainable management of peatlands. 


\section{Materials and methods}

\section{Study area}

The study was conducted in Kuala Langat South Forest Reserve (KLSFR), Selangor, Malaysia. This forest reserve is approximately 6908 ha. Two plots were selected to represents a virgin jungle reserve in Compartment $26\left(02^{\circ} 40^{\prime} 48.8^{\prime \prime} \mathrm{N}, 101^{\circ} 37^{\prime}\right.$ $10.6^{\prime \prime}$ E) and an adjacent agricultural land which is planted with banana (10 months old plants) and pineapple (12 months old plants - $\left.02^{\circ} 46^{\prime} 06.8^{\prime \prime} \mathrm{N}, 101^{\circ} 34^{\prime} 30.5^{\prime \prime} \mathrm{E}\right)$. From 2008 to 2019, the mean annual rainfall and temperature of the area were 1895 $\mathrm{mm}$ and $27.6^{\circ} \mathrm{C}$, respectively. The area is an ecosystem restoration project under the jurisdiction of the Selangor State Forestry Department, Malaysia. Compartment 26 was gazetted in 1926 (174 ha) and it is not logged. The virgin jungle reserve has several important peat swamp forest tree species such as meranti bunga (Shorea teysmanniana), kempas (Koompassia malaccensis), bintangor (Calophyllum spp.) and geronggang (Cratoxylum arborescens). Endangered wildlife such as tapir, sun bears, and white handed gibbon are also found in the area (FDPM/FRIM 2014). According to the neighbouring farmers, the agricultural land was leased in 1988 by the local agricultural development authorities for cash crop cultivation. The area is used for planting short-term crops to generate income for the local farmers. Currently, Compartment 7 ( $165 \mathrm{ha}$ ) is cultivated with bananas and pineapples, although information on the previous crop rotation is not documented. We established a $200 \times 100 \mathrm{~m}$ permanent sampling plot ( $2 \mathrm{ha}$ ) in each compartment to collect soil samples in addition to measuring fluxes from July 2018 to August 2019. Each site had eight random sampling points and they were chosen within a regular grid.

\section{Estimation of aboveground and belowground biomass}

The aboveground biomasses in the sites were estimated using remote sensing techniques. Phase Array L-Band Synthetic Aperture Radar (PALSAR) obtained from the Advance Land Observation Satellite (ALOS) was used. An aboveground biomass estimation model was developed to estimate $C$ stock of the experimental sites. Synthetic Aperture Radar (SAR) satellite images which were acquired in year 2017 from Phase Array L-Band Synthetic Aperture Radar 2 (PALSAR-2) system onboard Advance Land Observation Satellite 2 (ALOS2) satellite were used as the primary input. The images consisted of two polarizations, that is, horizontal-vertical (HV) and horizontal-horizontal $(\mathrm{HH})$ at 25 -m spatial resolution, geometrically and radiometrically corrected and normalized for topography. These data were generated by Earth Observation Research Center (EORC) under JAXA (Japan Aerospace Exploration Agency) and supplied by the Remote Sensing
Technology Center of Japan (RESTEC). In 2018, 84 sampling plots (21 clusters) were established in the study area. A cluster consisted of four plots (Fig. S1 in Supplementary material). The plots were circular with smaller nests (subset). The biggest nest measured $20 \mathrm{~m}$ in radius, followed by the smaller nests measuring $12 \mathrm{~m}$ and $4 \mathrm{~m}$ in radius. The trees were grouped by size, in classes, and thereafter, they were sampled based on the nest size. In addition to these nests, small nest measuring $2 \mathrm{~m}$ in radius was used to count saplings, i.e., trees measuring $<10 \mathrm{~cm}$ in diameter at breast height (dbh) and $>1.3 \mathrm{~m}$ in height. The range of trees which were measured in each nest of a sample plot are presented in Tab. S1 (Supplementary material). This design was developed by Walker et al. (2012) and modified to suit tropical forest stand conditions by Hamdan et al. (2018). The aboveground biomass was determined using an allometric equation (Chave et al. 2005) as follows (eqn. 1):

$$
\begin{aligned}
W_{t} & =0.65 \cdot \exp [-1.239+1.98 \cdot \ln (D) \\
& +0.207 \cdot \ln (D)^{2} \\
& \left.-0.0281 \cdot \ln (D)^{3}\right]
\end{aligned}
$$

The equation is suitable for moist tropical forests with $1500-4000 \mathrm{~mm}$ annual rainfall, where $D$ is the diameter at breast height in $\mathrm{cm}$ and $W_{t}$ is total aboveground biomass in $\mathrm{kg}$ tree $^{-1}$. The backscatter values from HV polarization from the two datasets were extracted from the images. The AGB values at the sample plots on the ground were correlated with the corresponding backscatter values using non-linear regression. This process produced several empirical models that were used to retrieve AGB of the study area. The estimation models used AGB as independent variable to observe the sensitivity of the backscatter to the AGB. The relationship between backscatter and $A G B$ is often represented in logarithmic function as follows (eqn. 2):

$$
y=a \cdot \ln (x)+b
$$

where $y$ is the aboveground biomass ( $\mathrm{Mg}$ ha $\left.{ }^{-1}\right), x$ is the backscatter of HV polarization, $a=4.29740$, and $b=-39.015$. For roots, the belowground biomass was estimated as $0.26 \cdot \mathrm{AGB}\left(\mathrm{Mg} \mathrm{ha}^{-1}\right)$, according to Cairns et al. (1997).

\section{Soil observation and characterization}

Soil sampling was done using an Eijkelkamp peat auger (dimension of $50 \mathrm{~cm}$ length and $5.2 \mathrm{~cm}$ in diameter) up to the depth of the mineral layer for each site at the beginning of the study (August 2018). The changes in colour, peat type, depth of horizon, and other features were recorded according to Soil Survey Staff (1993). Peat soil degree of decomposition is classified as sapric, hemic and fibric. Sapric is the highly decomposed material which contains one-third of fibre by volume after rubbing test. Hemic is the intermediate which is partially decomposed, containing fibre between one-third and two-thirds of the volume before rubbing. Fibric material constitutes more than two-thirds of undecomposed material by volume after rubbing (Soil Survey Staff 1999). The bulk density at different soil depths (based on pedological horizons) was determined using the coring method. Two replicates were collected at each horizon. Samples for bulk density were collected using a modified method using aluminium foils. The peat samples were retrieved using the extension auger, after which the samples were trimmed with a knife to $5 \mathrm{~cm}$ for uniformity. The individual samples were packed using aluminium foils after which they were kept in ziplock bags to avoid contamination. In the laboratory, the peat soil samples were weighed (with and without the aluminium foil) using a digital weighing balance after which they were oven dried at $65-70{ }^{\circ} \mathrm{C}$ (Walker et al. 2012, Jeyanny et al. 2016) until a constant weight was attained. This temperature range was chosen because of the organic nature of the peat soil samples. However, the mineral samples of sulfidic marine clay were oven dried at $105{ }^{\circ} \mathrm{C}$ for the bulk density determination.

Another set of independent soil samples were taken according to the pedological horizons for $\mathrm{pH}$ and electrical conductivity (EC) determination using the peat auger. The soil samples were also analysed for organic C using the Walkley \& Black (1934) method and Nitrogen ( $N$ ) by dry combustion method (Matejovic 1993) using a Tru$M a{ }^{\circledR}$ CNS analyser (LECO Corp., St. Joseph, MI, USA). Walkley \& Black (1934) method was used because there was a requirement to determine organic matter content of the samples for basic properties. Available phosphorus $(P)$ was determined using Bray and Kurtz Method II (Olsen et al. 1982). Exchangeable potassium (K), calcium (Ca), and magnesium (Mg) were extracted using $1 \mathrm{M}$ ammonium acetate $\left(\mathrm{NH}_{4} \mathrm{OAc}\right)$ calibrated at $\mathrm{pH} 7$ after which these cations were determined using atomic absorption spectrometry. Cation exchange capacity (CEC) was determined using the leaching method (Thomas 1982). Peat soil C stocks were calculated by multiplying the percentage of organic carbon (OC) by the bulk density of peat $\left(\mathrm{g} \mathrm{cm}^{-3}\right)$ at the measured peat depths $(\mathrm{cm})$ after which the values obtained were converted to $\mathrm{C} \mathrm{Cha}^{-1}$.

\section{Estimation of total soil respiration}

An automated soil $\mathrm{CO}_{2}$ flux system (LI$8100^{\circledast}, \mathrm{Li}-\mathrm{COR}$ Biosciences, Lincoln, NE, USA) was used to measure the peat soil $\mathrm{CO}_{2}$ fluxes into the atmosphere. The instrument was calibrated twice within the duration of measurement using a standard $\mathrm{CO}_{2}$ gas. Also, the zero and span procedure before measurements were recorded. Measurements were taken between 10:00 and 12:00 p.m. This was based on the assumption that the daily soil $\mathrm{CO}_{2}$ fluxes were higher during this duration (Luo \& Zhou 
2006). Thus, eight replications of soil collars placed randomly for each site were used because of the complexity of the sites (limited access because of overgrowth and water inundation). Before the beginning of the measurement of the $\mathrm{CO}_{2}$ emission, soil collars (radius: $10 \mathrm{~cm}$; height: $10 \mathrm{~cm}$ ) were placed on the soil surface and inserted into the soil, leaving a headspace of $3 \mathrm{~cm}$. Soil disturbance during collar insertion was minimized. Measurements were carried out from August 2018 to August 2019. During the $\mathrm{CO}_{2}$ emission measurement (two months interval), the lid of the chamber was closed to enable the air to circulate in the gap between the collar headspace and the chamber. Once the $\mathrm{CO}_{2}$ concentration in the chamber had stabilised (approximately 30 seconds), the concentration was recorded for approximately 60 seconds. Each measurement was repeated twice at each sampling point. The $\mathrm{CO}_{2}$ flux rate was determined using the Li-8100 A 4.0.9 systems software by calculating the initial slope of a fitted exponential curve at the ambient $\mathrm{CO}_{2}$ concentration. The units for this measurement were $\mu \mathrm{g} \mathrm{mol} \mathrm{CO}_{2} \mathrm{~m}^{-2} \mathrm{~s}^{-1}$. These values were converted to $\mathrm{mg} \mathrm{CO}_{2} \mathrm{~m}^{-2}$ $\mathrm{h}^{-1}$ using a mathematical function and reported as total soil respiration.

\section{Measurements of ancillary variables}

At each time of soil respiration measurement, eight replicates of bulk density samples (one per sampling point) at $5 \mathrm{~cm}$ depth at each site were taken using core rings of $100 \mathrm{~cm}^{3}$. These soil samples were taken near the soil flux measurement sampling point to determine soil porosity and volumetric soil water content. Water filled pore space (WFPS) was calculated from the soil water content and bulk density. The particle density value which was used for organic matter was one $\mathrm{g} \mathrm{cm}^{-3}$ as recommended by Brady \& Weil (2002) and Rixen et al. (2016) for peat samples. Soil bulk density and soil water content were determined by recording the initial weight of the soils. Afterwards, they were oven dried at $105{ }^{\circ} \mathrm{C}$ until constant weight was attained. Water filled pore space (WFPS), which is the ratio of volumetric water content to total porosity of the peat soil was calculated. The peat soil temperature was determined using an additional temperature probe. The probe was inserted in the peat soil at a $5 \mathrm{~cm}$ depth and measurement was taken when the values stabilized $( \pm 5$ seconds). Relative humidity was determined using $\mathrm{LI}-8100 \mathrm{CO}_{2}$ flux system.

Groundwater monitoring well was used to monitor the groundwater level (GWL) fluctuation at the experimental sites. The device is made of a two inch PVC (polyvinyl chloride) pipe with $8 \mathrm{~mm}$ holes to enable water to enter the monitoring well. The top of the pipe was closed with an end cap to prevent debris. The pipe was marked with the station number. A filtering net was used to wrap the PVC before it was inserted in the soil to prevent sedimentation.
The PVC pipe was inserted in the mineral layer. The monitoring well was installed at the selected forest compartment on a transect of $300 \mathrm{~m}$ with an interval of $100 \mathrm{~m}$ measured from a river/channel/compartment boundary towards the forest. The GWL was measured by dipping a dry measuring stick or measuring tape inside the monitoring well. Water table depth was computed by subtracting the depth of the measuring point above the ground surface from the depth recorded between the water surface to the measuring point of the well. Values indicating water level below the ground surface were recorded negative whereas the values obtained above ground surface were recorded as positive values.

\section{Meteorological data}

Meteorological data for the duration of this study were obtained from the National Meteorological Department of Malaysia. The nearest weather stations from which data were obtained were at Banting (GPS: $02^{\circ} 49^{\prime} \mathrm{N}, 101^{\circ} 30^{\prime} \mathrm{E}$ ), Malaysia and Kuala Lumpur International Airport, Sepang ( $02^{\circ}$ $\left.43^{\prime} \mathrm{N}, 101^{\circ} 42^{\prime} \mathrm{E}\right)$, Malaysia. The data were downloaded from August 2018 to August 2019. The rainfall ranged from 54.2 to 378.2 $\mathrm{mm}$ (Fig. S2 in Supplementary material). Because the climate in Malaysia is controlled by two monsoon seasons, heavy rainfall is expected from October to March (wet season), whereas May to September are relatively drier. The wet season (September to December 2018) and the dry season (July to August 2018, and August 2019) had high and low precipitations, respectively. Lower air temperature was recorded $\left( \pm 27.0^{\circ} \mathrm{C}\right)$ during the wet season whereas higher air temperature $\left(28\right.$ and $29^{\circ} \mathrm{C}$ ) was recorded during the dry season.

\section{Statistical analysis}

All the measured variables were subjected to normality test using the ShapiroWilks test. To compare the differences of soil respiration and environmental variables across sampling time at the two experimental sites, normally distributed data were subjected to Analysis of variance (ANOVA), while non-normal data were subjected to Kruskal-Wallis test. A probability threshold of 0.05 was used to determine significant effects. Means which were normally distributed were compared using Student Newman-Keul (SNK) test. Pearson

Tab. 1 - Carbon stocks ( \pm standard error) for different tropical peatland uses. Mineral substratum depth: (a) $1.75 \mathrm{~m}$; (b) $3.80 \mathrm{~m}$.

\begin{tabular}{lcc}
\hline \multirow{2}{*}{ Carbon pools } & \multicolumn{2}{c}{ Carbon stocks $\left(M_{g}\right.$ C ha $\left.^{-1}\right)$} \\
\cline { 2 - 3 } & \multicolumn{1}{c}{ Mixed crops } & Forest \\
\hline Aboveground biomass & $42.60 \pm 6.89$ & $153.10 \pm 24.38$ \\
Belowground biomass (roots) & $11.08 \pm 1.79$ & $39.81 \pm 6.33$ \\
Peat soil (up to mineral substratum) & $969.89^{\text {(a) }}$ & $1595.88^{(\mathrm{b})}$ \\
\hline Total ecosystem & 1023.57 & 1788.79 \\
\hline
\end{tabular}

correlation analysis was used to determine the relationship among the environmental variables. The statistical analyses were conducted using the software $\mathrm{SAS}^{\circledR}$ ver. 9.4 (SAS Institute, Cary, NC, USA). For aboveground biomass, the estimation was validated using the $k$-fold cross-validation method, which is a technique that is used to evaluate a predictive model by dividing the original sample into (i) a training set to train the model and (ii) a test set to evaluate the model. The cross-validation process was repeated $k$ times (the folds), with each of the $k$ subsamples used exactly once as the validation data (McLachlan et al. 2005).

\section{Results and discussion}

Results for aboveground biomass which was measured according to logarithmic function showed that the eqn. 2 was significant at 95\% confidence interval (data not shown). The estimated aboveground biomass, measured according to tree size was accurate with a RMSE value of \pm 62.70 $\mathrm{Mg} \mathrm{ha}^{-1}$ and a mean absolute percentage error (MAPE) of $18.5 \%$. This accuracy was considered sufficient for the present study (Omar \& Misman 2018). The aboveground biomass at the forest site was 3.5 folds relatively higher compared to the mixed crop site (Tab. 1).

The field and laboratory results are presented in Tab. 2 and Tab. S2 (Supplemenary material). The two experimental sites showed different peat soil profile characteristics. The forest peat soil profile revealed decomposed woody material below $75 \mathrm{~cm}$ with a parent material depth greater than $3.8 \mathrm{~m}$, whereas the soil profile of the mixed crops site showed very little decomposing wood and a shallower depth (1.75 $\mathrm{m})$. Fibric material was found in the mixed crops site but this material was not present in the forest site. Peat soils which are often cultivated with plantation crops or cash crops reduce in depth with cultivation time because of subsidence which is difficult to control even with good drainage system (Hooijer et al. 2010, Hergoualch et al. 2017). The $\mathrm{pH}$ (2.8-3.9) and bulk density (0.120.49) of the two experimental sites were relatively low (Tab. 1) although the values are typical of those peat soils. The low $\mathrm{pH}$ and bulk density of the two sites suggest that the soils of the two sites are acidic in addition to having a lower bearing capacity (Tab. 1). Carbon decreased with increasing classes (Tab. S1 in Supplementary material) 
Tab. 2 - Selected soil physical and chemical properties of mixed cropping and forest swamp plots. (BD): bulk density; (EC): electric conductivity; (BS): base saturation; (CEC): cation exchange capacity.

\begin{tabular}{|c|c|c|c|c|c|c|c|c|c|c|c|c|}
\hline \multirow[b]{2}{*}{ Soil properties } & \multicolumn{4}{|c|}{ Mixed crops (soil depth, $\mathrm{cm}$ ) } & \multicolumn{5}{|c|}{ Forest (soil depth, cm) } & \multirow[b]{2}{*}{$\begin{array}{l}\text { 오 } \\
\text { on } \\
\end{array}$} & \multirow[b]{2}{*}{ 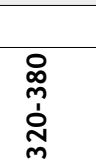 } & \multirow[b]{2}{*}{ 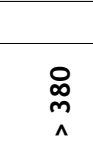 } \\
\hline & $\frac{N}{o}$ & 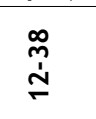 & $\begin{array}{l}\text { L } \\
\infty \\
1 \\
\infty \\
m\end{array}$ & 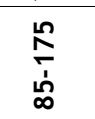 & $\frac{n}{\stackrel{n}{x}}$ & $\frac{n}{\grave{c}}$ & $\begin{array}{l}\text { 우 } \\
\text { ஸ่ } \\
\text { م }\end{array}$ & 음 & $\frac{\text { 음 }}{\frac{1}{8}}$ & & & \\
\hline $\mathrm{pH}$ & 3.87 & 3.86 & 3.87 & 3.9 & 2.88 & 3.16 & 3.18 & 3.63 & 3.34 & 3.87 & 3.58 & 3.27 \\
\hline $\mathrm{BD}\left(\mathrm{g} \mathrm{cm}^{-3}\right)$ & 0.24 & 0.12 & 0.47 & 0.85 & 1.08 & 0.19 & 0.16 & 0.17 & 0.18 & 0.23 & 0.49 & 0.98 \\
\hline $\mathrm{EC}\left(\mathrm{ds} \mathrm{\textrm {m } ^ { - 1 } )}\right.$ & 1.5 & $<0.1$ & 1.3 & 2.1 & 16.5 & 3.8 & 2.3 & 1.6 & 1.4 & 1.5 & 15 & 24 \\
\hline BS $(\%)$ & 56.62 & 10.77 & 36.52 & 18.41 & 193.36 & 33.98 & 46.01 & 7.11 & 33.56 & 169.44 & 49.83 & 110.04 \\
\hline Organic C (\%) & 30.28 & 25.51 & 23.56 & 3.71 & 3.4 & 31.56 & 31.67 & 31.81 & 32.22 & 30.68 & 10.96 & 7.12 \\
\hline Total N (\%) & 0.96 & 0.62 & 0.65 & 0.13 & 0.13 & 1.91 & 0.84 & 0.73 & 0.66 & 0.73 & 0.33 & 0.25 \\
\hline $\mathrm{C}: \mathrm{N}$ & 32 & 41 & 36 & 30 & 27 & 17 & 38 & 44 & 49 & 42 & 33 & 28 \\
\hline Availaible $\mathrm{P}\left(\mathrm{mg} \mathrm{kg}^{-1}\right)$ & 82 & 22 & 89 & 11 & 12 & 102 & 15 & 2 & 1 & 2 & 16 & 21 \\
\hline CEC $\left(\mathrm{cmol} \mathrm{kg}^{-1}\right)$ & 1.2 & 5.8 & 2 & 7.3 & 18 & 2.5 & 1.4 & 1.8 & 1.8 & 1 & 36.2 & 26.9 \\
\hline $\mathrm{K}\left(\mathrm{cmol} \mathrm{kg}^{-1}\right)$ & 0.04 & 0.02 & 0.02 & 0.04 & 0.63 & 0.04 & 0.01 & 0.01 & 0.01 & 0.99 & 0.9 & 0.08 \\
\hline $\mathrm{Ca}\left(\mathrm{cmol} \mathrm{kg}{ }^{-1}\right)$ & 0.48 & 0.47 & 0.56 & 0.78 & 5.1 & 0.63 & 0.52 & 0.01 & 0.51 & 0.54 & 2.3 & 9.76 \\
\hline $\mathrm{Mg}\left(\mathrm{cmol} \mathrm{kg}^{-1}\right)$ & 0.07 & 0.06 & 0.07 & 0.39 & 12.35 & 0.12 & 0.06 & 0.06 & 0.05 & 0.07 & 11.18 & 13.29 \\
\hline $\mathrm{Na}\left(\mathrm{cmol} \mathrm{kg}^{-1}\right)$ & 0.08 & 0.08 & 0.08 & 0.14 & 16.67 & 0.05 & 0.04 & 0.04 & 0.04 & 0.06 & 3.66 & 6.44 \\
\hline $\operatorname{Mn}\left(\mathrm{mg} \mathrm{kg}^{-1}\right)$ & 5.15 & 0.62 & 2.15 & 1.56 & 20.78 & 1.65 & 0.84 & 0.87 & 1.09 & 1.05 & 11 & 17.03 \\
\hline $\mathrm{Cu}\left(\mathrm{mg} \mathrm{kg}^{-1}\right)$ & 1.17 & 0.64 & 0.82 & 0.58 & 0.706 & 0.74 & 0.52 & 0.7 & 0.78 & 0.5 & 0.54 & 0.67 \\
\hline $\mathrm{Fe}\left(\mathrm{mg} \mathrm{kg}^{-1}\right)$ & 44.41 & 15.14 & 6.56 & 9.39 & 84.78 & 23.01 & 25.54 & 6.2 & 5.58 & 4.17 & 4.15 & 13.84 \\
\hline $\mathrm{Zn}\left(\mathrm{mg} \mathrm{kg}^{-1}\right)$ & 5.85 & 0.35 & 3.96 & 0.29 & 7.65 & 4.76 & 0.46 & 0.47 & 0.31 & 0.18 & 6.3 & 6.86 \\
\hline
\end{tabular}

soil depth. The soil CEC of the two sites de- the top layer of the mixed crop site. The creased down the soil profile. The ex- soil $\mathrm{pH}$, bulk density, and $\mathrm{C}$ values were changeable bases ( $\mathrm{K}, \mathrm{Ca}, \mathrm{Mg}, \mathrm{Na}$ ) of the consistent with those reported in the Soil two experimental sites were less than 1 Survey Staff (2018). The CEC values of peat $\mathrm{cmol} \mathrm{kg}^{-1}$ except for the forest site depth of soils are generally greater than $10 \mathrm{cmol} \mathrm{kg}^{-1}$ 320-380 cm, whose $\mathrm{Ca}, \mathrm{Mg}$, and $\mathrm{Na}$ were (Paramananthan 2000, 2016) but those regreater than $1 \mathrm{cmol} \mathrm{kg}^{-1}$. Trace elements ported in the present study were lower be$(\mathrm{Mn}, \mathrm{Cu}, \mathrm{Fe}$, and $\mathrm{Zn}$ ) were detected only in cause of the lower exchangeable bases.

Tab. 3 - P-value for differences among different sampling intervals in mixed crops and forest swamp sites using ANOVA or Kruskall-Wallis tests. (BD): bulk density; $(T)$ : temperature; $(\mathrm{RH})$ : relative humidity; (WFPS): water filled pore space; (GWL): ground water level.

\begin{tabular}{lcc}
\hline Variable & Mixed crops & Forest \\
\hline Soil Flux & 0.019 & $<0.001$ \\
\hline Soil BD & 0.573 & 0.014 \\
\hline RH & $<0.0004$ & $<0.0001$ \\
\hline Soil T & 0.014 & 0.014 \\
\hline WFPS & 0.563 & 0.007 \\
\hline GWL & 0.006 & 0.006 \\
\hline
\end{tabular}

Tab. 4 - Correlations among selected soil properties and climatic parameters for mixed crops site. (Soil T): Soil temperature; (RH): Relative humidity; (WFPS): water filled pore space; (GWL): ground water level; $(*): p<0.05 ;(* *): p<0.01 ;(* * *): p<$ 0.001 .

\begin{tabular}{lccccc}
\hline Variable & Soil T & RH & Rainfall & WFPS & GWL \\
\hline Soil Flux & -0.158 & $-0.262^{*}$ & 0.092 & -0.172 & -0.198 \\
\hline Soil T & - & -0.004 & -0.113 & -0.139 & -0.139 \\
\hline RH & - & - & -0.122 & -0.042 & $0.419^{*}$ \\
\hline Rainfall & - & - & - & -0.186 & $-0.557^{* * *}$ \\
WFPS & - & - & - & - & $-0.470^{* *}$ \\
\hline
\end{tabular}

The ECs of the two peat soils were higher compared with those reported by Girkin et al. (2018) and Ishikura et al. (2018) for Panama peatlands $\left(0.014 \mathrm{dS} \mathrm{m}^{-1}\right)$ and Central Kalimantan, Indonesia peatlands ( 0.010

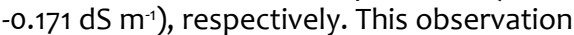
is related to the differences in precipitation, ground water levels, colonisation of the mangroves during the Holocene (Cooper et al. 2020), and sulfidic marine clay parent material (Tab. S2 in Supplementary material).

The ecosystem $C$ stocks (biomass and peat soil up to the mineral substratum)

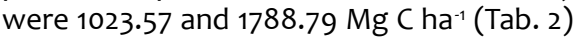
for mixed crops and forest site, respectively. The ecosystem $\mathrm{C}$ stocks in the swamp forest was relatively higher (74\%) compared to the mixed crops site. The ecosystem C distribution was in the order of the soil C in the peat (89-95\%), followed by aboveground (4-8\%), and belowground biomass (1-2\%). The soil $\mathrm{C}$ in the forest plot was higher than in the mixed crop site clearly due to the differences in the soil depths of these sites. The forest $C$ stocks are comparable to those reported for uncultivated peatlands (Page et al. 2011, Paramananthan 2016).

In the present study, we determined the changes in environmental parameters between sites at different sampling periods to understand the factors affecting soil carbon dioxide fluxes (Tab. 3). The soil fluxes, relative humidity, and soil temperature were significantly different across sampling time. The fluxes in the forest site were significantly different $(p=0.019)$ but the difference at the mixed crops site was signifi- 


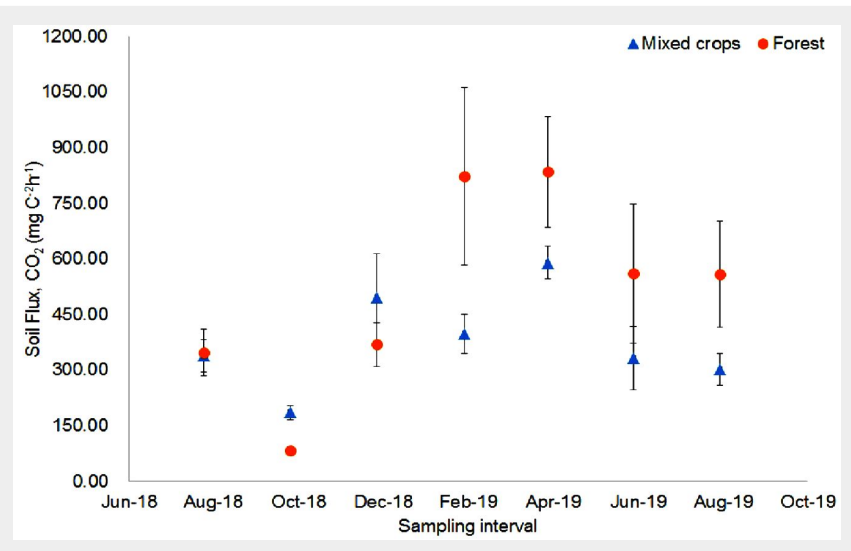

Fig. 1 - Soil carbon dioxide fluxes in at study site (August 2018 August 2019). Vertical bars denote standard error $(n=8)$.

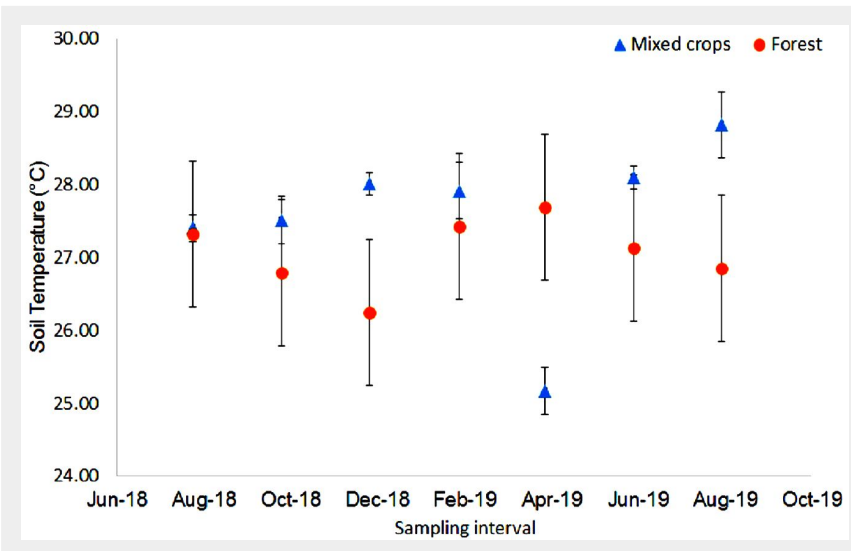

Fig. 2 - Soil temperature at study site (August 2018 - August 2019). Vertical bars denote standard error $(n=8)$. cantly higher $(p \leq 0.001)$. The relative humidity ( $\leq 0.001)$ and ground water levels $(p=0.006)$ at the two experimental sites varied significantly. Relative humidity is controlled by environmental factors such as air temperature and moisture (Fig. S2 in Supplementary material). The ground water levels of both sites were controlled by rainfall and canal control gauge (Tab. 4). Soil bulk density $(p=0.014)$ and water filled pore space $(p=0.007)$ were significantly different in the forest plot.

The soil $\mathrm{CO}_{2}$ fluxes (Rs) were significantly different. In the forest plot, higher fluxes (559.15-834.77 mg $\mathrm{CO}_{2} \mathrm{~m}^{-2} \mathrm{~h}^{-1}$ ) occurred from February 2019 to August 2019 (Fig. 1). For the mixed crops plot, the Rs were significantly different but higher fluxes were recorded in December 2018 (495.79 $\mathrm{mg} \mathrm{CO}_{2}$ $\left.\mathrm{m}^{-2} \mathrm{~h}^{-1}\right)$ and April 2019 (589.24 mg CO $\mathrm{m}^{-2}$ $\left.\mathrm{h}^{-1}\right)$. There were differences in the soil temperature and the forest plot showed lower values (Fig. 2). In December 2018, there was a significant soil temperature change (Fig. 2). The highest soil temperature was recorded in April $2019\left(27.69^{\circ} \mathrm{C}\right)$ for forest plot and in August $2019\left(28.81^{\circ} \mathrm{C}\right)$ for the mixed crops plot.

The experimental sites had different relative humidity and difference was prominent in the mixed crops plot (Fig. 3) be- cause the relative humidity fluctuated between $74.46 \%$ and $95.63 \%$. Higher relative humidity values were observed from October to December 2018 and in June 2019. However, in the forest plot the relative humidity was relatively stable (77.06\%-82.51\%). The relative humidity values for the mixed crops plot from October to December 2018 and in June 2019 were higher because of microclimate effects.

The changes in soil $\mathrm{CO}_{2}$ fluxes, soil temperature, and relative humidity could be related to rainfall, ground water level, and air temperature patterns because for example, during the dry period, soil $\mathrm{CO}_{2}$ emission was high in the forest site and the opposite was true in the wet season. The $\mathrm{CO}_{2}$ emission during the dry season was due to high temperature and oxidative peat decomposition (Hooijer et al. 2010, Choo \& Ahmed 2014). High temperature lowers water table and causes rapid peat soil decomposition. This observation compares with those of Girkin et al. (2018) and Lee et al. (2019). In the mixed crops site, the higher soil $\mathrm{CO}_{2}$ in December 2018 and April 2019 could be ascribed to the higher relative humidity (October and December 2018) and agricultural activities such as fertilization and clearing. High humidity, land clearing, and fertilization favour microbial activities of microorganisms to enhanced soil respiration (Luo \& Zhou 2006, Jauhiainen et al. 2014). Thus, land management strategies drive changes in $\mathrm{CO}_{2}$ emissions in cultivated land.

Only bulk density values $\left(0.17-0.23 \mathrm{~g} \mathrm{~cm}^{-3}\right)$ of the forest plot were significantly different (Fig. 4). The bulk density values were similar to those of an adjacent tropical peat swamp forest in North Selangor Peat Swamp Forest (Cooper et al. 2020).

The values of WFPS were relatively lower in the mixed crops plot than in the forest plot (Fig. S3 in Supplementary material). In the forest plot, WFPS was generally greater than $75 \%$ (Fig. S3). Regardless of time of sampling, the GWL of the forest plot was relatively higher compared with the mixed crops plot (Fig. 5). The GWL remained high from August to December 2018 but it decreased from February to April 2019, except in June 2019 (Fig. 5). The changes in the GWL in the two sites are related to the rainfall patterns and control of water flow through the canals built by the Forestry Department of Malaysia. The canals were constructed not only for prevention of peat fires but to also reduce peat oxidation and subsidence (Melling \& Henson 2011). For oil palm plantations, a range of -40 to $-60 \mathrm{~cm}$ is recommended for main-

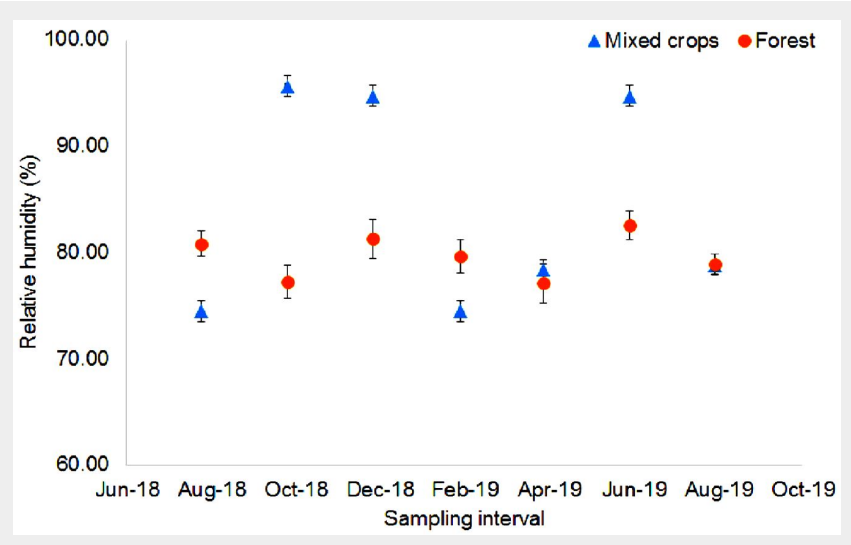

Fig. 3 - Relative humidity at the study site (August 2018 August 2019). Vertical bars denote standard error $(n=6)$.

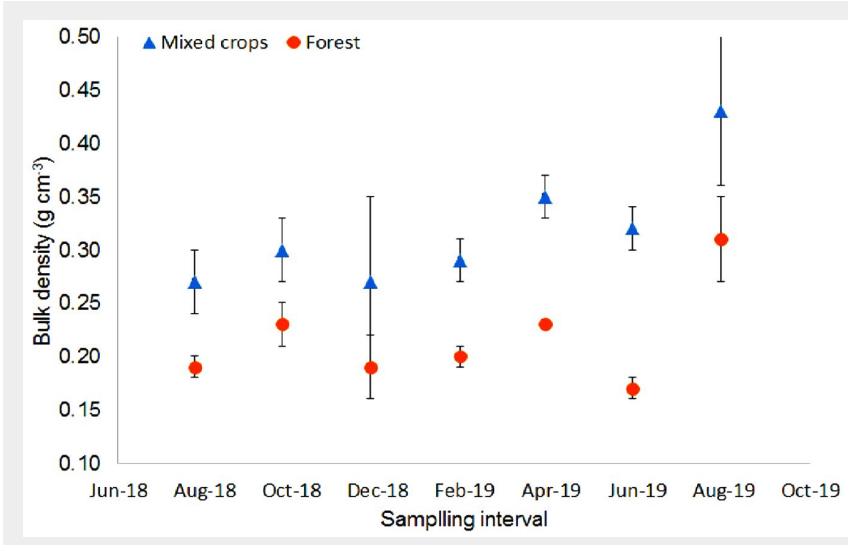

Fig. 4 - Peat bulk density values at the study site (August 2018 August 2019). Vertical bars denote standard error $(n=4)$. 


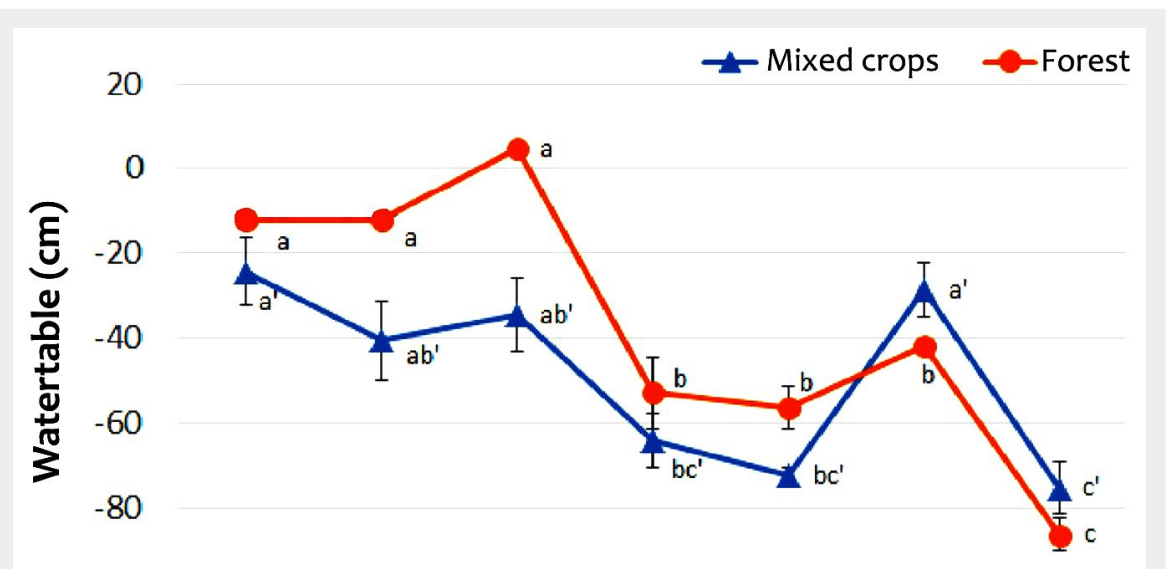

$-100$

Aug-18 Oct-18 Dec-18 Feb-19 Apr-19 Jun-19 Aug-19

\section{Sampling interval}

Fig. 5 - Ground water level at the study site (August 2018 - August 2019). Vertical bars denote standard error $(n=4)$. Individual points labelled with the same letters are not significantly different $(p>0.05)$ according to SNK test.

taining the water table (Page et al. 2011,
Jauhiainen et al. 2012). This is the standard set by the Roundtable on Sustainable Palm Oil (RSPO) to minimize peat soil and carbon loss. Unlike the oil palm plantations, the cultivated peat soils with other crops (for example, mixed farming) are not restricted to the RSPO standard because water table fluctuations is driven by GHG such as methane $\left(\mathrm{CH}_{4}\right.$ - Cooper et al. 2020), temporal variation, climate or manual control of water flow. In such situations water table fluctuations within +10 to $-80 \mathrm{~cm}$ occur; for example the $-80 \mathrm{~cm}$ which was recorded in August 2019 (dry period) in the forest plot.

In the mixed crop plots, there was a significant correlation between relative humidity and soil fluxes (Tab. 5). Ground water levels significantly correlated with relative humidity, rainfall, and water filled pore space. However in the forest plot, soil fluxes, relative humidity, rainfall, and ground water level significantly correlated with soil temperature. For the forest plot, water filled pore space correlated with relative humidity and ground water level.

The mixed crops plot data (Tab. 5) suggest that rainfall had significant influence on groundwater levels and WFPS. Environmental factors controlling temporal varia-

tions in soil fluxes, WFPS, and GWL in forests are soil temperature, relative humidity, and rainfall. Factors such as other GHGs (methane and nitrous oxide), microbial respiration and peat subsidence (Cooper et al. 2020, Jauhiainen et al. 2014, Melling \& Henson 2011), though playing important roles, were not extensively explored here. Although the two sites showed some similarities, the climatic conditions at the forest plot were more diverse because of the spatial variability of species, microclimate, peat depth, organic debris, and microbial biomass (Berglund \& Berglund 2011, Hergoualch et al. 2017, Lee et al. 2019).

Oil palm cultivation on peats emits 19 to $94 \mathrm{tCO}_{2}$ ha $^{-1}$ year-1 (Page et al. 2011, Hergoualch et al. 2017, Cooper et al. 2020). Most peat swamp forests emit $\mathrm{CO}_{2}$ between 13.33 to 86.0 tCO $_{2}$ ha $^{-1}$ year ${ }^{-1}$ (Hooijer et al. 2010, Hergoualch \& Verchot 2014, Ishikura et al. 2018, Girkin et al. 2018). The emissions of 7.20 to $73.13 \mathrm{tCO}_{2}$ ha $^{-1}$ year ${ }^{-1}$ from the peat forest plot were lower, and this was due to the microclimate of the plot and the strict monitoring of the entire peat swamp forest by the Forest Department of Malaysia. For mixed farming (pineapple, cassava, rice, and soybean) 19.3 to $176.6 \mathrm{tCO}_{2}$ year ${ }^{-1}$ had been reported (Hooijer et al. 2010, Melling \& Henson 2011, Choo

Tab. 5 - Correlations among selected soil properties and climatic parameters for forest swamp site. (Soil T): Soil Temperature; (RH): Relative humidity; (WFPS): Water filled pore space; (GWL): Ground water table; $\left(^{*}\right): p<0.05 ;(* *): p<0.01 ;(* * *): p<0.001$.

\begin{tabular}{llllll}
\hline Variable & Soil T & RH & Rainfall & WFPS & GWL \\
\hline Soil Flux & $-0.312^{*}$ & -0.200 & 0.280 & 0.031 & -0.380 \\
\hline Soil T & - & $-0.354^{* *}$ & $-0.033^{* *}$ & -0.071 & $-0.506^{* * *}$ \\
\hline RH & - & - & -0.227 & $-0.366^{* *}$ & 0.616 \\
\hline Rainfall & - & - & - & -0.069 & -0.300 \\
\hline WFPS & - & - & - & - & $-0.499^{* * *}$ \\
\hline
\end{tabular}

\& Ahmed 2014). This emission is higher than the range (26.50 to $43.43 \mathrm{tCO}_{2}$ ha $^{-1}$ year ${ }^{-1}$ ) recorded in this present study, suggesting practicing mixed farming on peat soils could minimize $\mathrm{CO}_{2}$, as mixed farming since 1988 to date might have caused soil C stabilization in the long run.

Our findings suggest that management of tropical peatlands by the Forestry State Department of Malaysia and farmers who cultivated peat soils in Malaysia is essential, especially when land is scarce and peat land transitions to agricultural cash crops such as banana and pineapple is inevitable as an option for food security and income for farmers. The way forwards for good management practices of peatlands include control of water table levels during droughts, early warning system for fire occurrence, constant monitoring, and awareness of environmental variables to reduce peat subsidence and soil respirations that encourages carbon dioxide fluxes. For example, cash crop farmers can be advised to maintain water table at -40 to $-60 \mathrm{~cm}$, minimize synthetic fertilizers and promote biofertilizers that may lower $\mathrm{CO}_{2}$ emissions and promote agroforestry models with native peatland timber species with crops. The outcomes of this work could contribute to sustainable management of peatlands particularly, for cultivated peatlands.

\section{Conclusion}

There were no extreme differences in the peat physical and chemical properties in the mixed crops plot as compared to forest plot, except for shallower peat depth due to subsidence as well as lower $C$ pools due to biomass differences in the mixed crop plots, implying that land use change influences peat depth and characteristics. Future research should elucidate the minimum water table requirements for cash crop cultivation and forests that may allow sustainable farming and forest protection by minimizing peat loss. Relative humidity, soil temperature, and ground water levels had significant effect on soil carbon dioxide fluxes in peat swamp forest and mixed cropping sites. Soil fluxes were significantly higher in the dry season compared with the wet season for the forest plot and the opposite was true for the mixed crop plots. This study further shows how droughts can severely influence $\mathrm{CO}_{2}$ emissions and the need to introduce management strategies, such as ground cover or fast growing native peat swamp species with the inclusion of water management measures, to reduce $\mathrm{CO}_{2}$ emissions. Long term research should also capture contributions of microbial population and processes related to carbon and root respiration in different sites with varying vegetation cover. Ground water levels correlated with rainfall, water filled pore space, and relative humidity. At the mixed cropping site, soil carbon dioxide fluxes correlated with relative humidity whereas for the forest site, soil temperature correlated with relative humidity, rain- 
fall, ground water level, and soil carbon dioxide fluxes. Long term understanding of temporal changes of tropical peatlands with varying land use is crucial to predict regional carbon balance model and pave the way to sustainable mitigation measures for climate adaptation.

\section{Acknowledgements}

We are indebted to the Forestry Department of Selangor for providing the research funds and other assistance related to this research. We are also grateful to the personnel of the Global Environment Facility (GEF) for providing basic information on the experimental sites. The staff of Forest Research Institute of Malaysia (FRIM) are acknowledged for the field and laboratory assistance rendered.

\section{References}

Abdullah FA, Samah BA, Othman J (2012). Inclination towards agriculture among rural youth in Malaysia. Journal of Basic and Applied Science Research 2: 10892-10894. [online] URL: http://www.researchgate.net/publication/3060 17192

Berglund O, Berglund K (2011). Influence of water table level and soil properties on emissions of greenhouse gases from cultivated peat soil, Soil Biology and Biochemistry 43: 923-931. - doi: 10.1016/j.soilbio.2011.01.002

Brady NC, Weil RR (2002). Soil and the hydrologic cycle. In: "The Nature and Properties of Soils". Pearson-Prentice Hall, NJ, USA, pp. 219271.

Cairns MA, Brown S, Helmer EH, Baumgardner GA (1997). Root biomass allocation in the world's upland forests. Oecologia 111: 1-11. - doi: 10.1007/s004420050201

Chave J, Andalo C, Brown S, Cairns MA, Chambers JQ, Eamus D, Fölster H, Fromard F, Higuchi $\mathrm{N}$, Kira T, Lescure JP (2005). Tree allometry and improved estimation of carbon stocks and balance in tropical forests. Oecologia 145: 87-99. doi: 10.1007/s00442-005-0100-x

Choo LNLK, Ahmed OH (2014). Partitioning carbon dioxide emission and assessing dissolved organic carbon leaching of a drained peatland cultivated with pineapple at Saratok, Malaysia. The Scientific World Journal, artID 906021. doi: $10.1155 / 2014 / 906021$

Cooper HV, Evers S, Aplin P, Crout N, Dahalan MPB, Sjogersten S (2020). Greenhouse gas emissions resulting from conversion of peat swamp forest to oil palm plantation. Nature Communications 11: 1-8. - doi: 10.1038/s41467019-13993-7

Dargie GC, Lewis SL, Lawson IT, Mitchard ETA, Page SE, Bocko YE, Ifo SA (2017). Age, extent and carbon storage of the central Congo Basin peatland complex. Nature 542 (7639): 86-90. doi: $10.1038 /$ nature 21048

FDPM/FRIM (2014). Report on blueprint for Kuala Langat Forest Reserve (KLFR). Institutional Report, Forestry Department of Peninsular Malaysia (FDPM) and Forest Research Institute Malaysia (FRIM), Selangor, Malaysia, pp. 44.

Girkin NT, Turner BL, Ostle N, Sjögersten S (2018). Root-derived $\mathrm{CO}_{2}$ flux from a tropical peatland. Wetlands Ecology and Management 26: 985-991. - doi: 10.1007/s11273-018-9617-8

Hamdan O, Norsheilla MJC, Ismail P, Samsudin M, Wan Abdul Hamid Shukri WAR, Azmer M (2018). Forest reference emission level for REDD+ in Pahang, Malaysia. Research Pamphlet No. 141, Forest Research Institute Malaysia (FRIM), Selangor, Malaysia, pp. 97. [online] URL: http://www.cabdirect.org/cabdirect/abstr act/20193179612

Hergoualch K, Verchot LV (2014). Greenhouse gas emission factors for land use and land-use change in Southeast Asian peatlands. Mitigation and Adaptation Strategies for Global Change 19: 789-807. - doi: 10.1007/s11027-013-95 $11-x$

Hergoualch K, Hendry DT, Murdiyarso D, Verchot LV (2017). Total and heterotrophic soil respiration in a swamp forest and oil palm plantations on peat in Central Kalimantan, Indonesia. Biogeochemistry 135: 203-220. - doi: 10.1007/s1053 3-017-0363-4

Hooijer A, Page S, Canadell JG, Silvius M, Kwadijk J, Wosten H, Jauhiainen J (2010). Current and future $\mathrm{CO}_{2}$ emissions from drained peatlands in Southeast Asia. Biogeosciences 7: 1505-1514. doi: 10.5194/bg-7-1505-2010

Ishikura K, Darung U, Inoue T, Hatano R (2018). Variation in soil properties regulate greenhouse gas fluxes and global warming potential in three land use types on tropical peat. Atmosphere 9 (12): 465. - doi: 10.3390/atmos9120465 Ishikura K, Yamada H, Toma Y, Takakai F, Morishita T, Darung U, Limin A, Limin SH, Hatano R (2017). Effect of groundwater level fluctuation on soil respiration rate of tropical peatland in Central Kalimantan, Indonesia. Soil Science and Plant Nutrition 63: 1-13. - doi: 10.1080/003807 68.2016.1244652

Jauhiainen J, Hooijer A, Page S (2012). Carbon dioxide emissions from an Acacia plantation on peatland in Sumatra, Indonesia. Biogeosciences 9: 617-630. - doi: 10.5194/bg-9-617-2012

Jauhiainen J, Kerojoki O, Silvennoinen H, Limin S, Vasander $\mathrm{H}$ (2014). Heterotrophic respiration in drained tropical peat is greatly affected by temperature a passive ecosystem cooling experiment. Environmental Research Letters 9 (10): 105013. - doi: 10.1088/1748-9326/9/10/105013

Jeyanny V, Balasundram SK, Husni MHA, Wan Rasidah K (2016). Spatial variability of forest floor thickness for estimation of refined carbon stocks in a tropical montane forest. Journal of Tropical Forest Science 28: 285-297. [online] URL: http://www.jstor.org/stable/43856533

Lee LY, Ahmed OH, Jalloh MB (2019). Brief review on climate change and tropical peatlands. Geoscience Frontiers 10: 373-380. - doi: 10.1016/ j.gsf.2017.12.018

Luo Y, Zhou X (2006). Soil respiration and the environment. Academic Press, Burlington, MA, USA, pp. 328.

Manning FC, Kho LK, Hill TC, Cornulier T, Teh YA (2019). Carbon emissions from oil palm plantations on peat soil. Frontiers in Forests and Global Change 2: 577. - doi: 10.3389/ffgc.2019.00037 Matejovic I (1993). Determination of carbon, hydrogen, and nitrogen in soils by automated elemental analysis (dry combustion method). Communications in Soil Science and Plant Analysis 24: 2213-2222. - doi: 10.1080/001036293093
68950

McLachlan GJ, Do KA, Ambroise C (2005). Analyzing microarray gene expression data (vol. 422). John Wiley and Sons, Hoboken, NJ, USA, pp. 368. [online] URL: http://books.google. com/books?id=gt8JNQfpnMIC

Melling L, Henson IE (2011). Greenhouse gas exchange of tropical peatlands. A review. Journal of Oil Palm Research 23: 1087-1095.

Melling L (2016). Peatland in Malaysia. In: "Tropical Peatland Ecosystems" (Osaki M, Tsuji N eds). Springer, Tokyo, Japan, pp. 59-74. - doi: 10.1007/978-4-431-55681-7_4

Melling L, Hatano R, Goh KJ (2005). Soil $\mathrm{CO}_{2}$ flux from three ecosystems in tropical peatland of Sarawak, Malaysia. Tellus B: Chemical and Physical Meteorology 57: 1-11. - doi: 10.3402/tellusb. v57i1.16772

Murphy DJ (2014). The future of oil palm as a major global crop: ppportunities and challenges. Journal of Oil Palm Research 26: 1-24. [online] URL: http://jopr.mpob.gov.my/wp-content/upl oads/2014/03/joprv26mac2014-denis1.pdf

Olsen SR, Sommers LE, Page AL (1982). Phosphorous. In: "Methods of soil analysis. Part 2: Chemical and Biological Properties" (Page AL, Miller RH, Keeney DR eds). ASA/SSSA, Madison, WI, USA. pp. 403-430.

Omar H, Misman MA (2018). Time-series maps of aboveground biomass in dipterocarps forests of Malaysia from PALSAR and PALSAR-2 polarimetric data. Carbon Balance and Management 13: 1-19. - doi: 10.1186/s13021-018-0108-2

Page SE, Rieley JO, Banks CJ (2011). Global and regional importance of the tropical peatland carbon pool. Global Change Biology 17: 798-818. - doi: 10.1111/j.1365-2486.2010.02279.x

Paramananthan S (2000). Soils of Malaysia Their characteristics and identification. Academy of Sciences Malaysia and Param Agricultural Soil Surveys, Kuala Lumpur, Malaysia, pp. 616. [online] URL: http://www.cabdirect.org/ cabdirect/abstract/20023037594

Paramananthan S (2016). Introduction to tropical peatlands. Tour Bulletin, Forest Research Institute Malaysia and Param Agricultural Soil Surveys, Kuala Lumpur, Malaysia, pp. 15.

Parish F, Sirin A, Charman D, Joosten H, Minayeva T, Silvius M, Stringer (2008). Assessment on peatlands, biodiversity and climate change: main report. Global Environment Centre, Kuala Lumpur; Malaysia and Wetlands International, Wageningen. Netherlands, pp. 206.

Rixen T, Baum A, Wit F, Samiaji J (2016). Carbon leaching from tropical peat soils and consequences for carbon balances. Frontiers in Earth Science 4: 74. - doi: 10.3389/feart.2016.00074 Soil Survey Staff (1993). Soil survey manual. Natural Resources Conservation Service, USDA, Washington, DC, USA, pp. 315.

Soil Survey Staff (1999). A basic system of soil classification for making and interpreting soil surveys. Natural Resources Conservation Service, USDA, Washington, DC, USA, pp. 886.

Soil Survey Staff (2018). Common soils of Peninsular Malaysia: soil profile description and analytical data. Soil Resource Management Division, Department of Agriculture, Putrajaya, Malaysia, pp. 414.

Thomas GW (1982). Exchangeable cations. In: "Methods of soil analysis. Part 2: Chemical and 
microbiological properties ( $2^{\text {nd }}$ edn)" (Page AL, Miller RH, Kelley DR eds). American Society of Agronomy, Madison WI, USA, pp. 159-165.

Vijay V, Pimm SL, Jenkins CN, Smith SJ (2016). The impacts of oil palm on recent deforestation and biodiversity loss. PLoS One 11: e0159668. doi: 10.1371/journal.pone.0159668

Walker SM, Pearson TRH, Casarim FM, Harris N, Petrova S, Grais A, Swails E, Netzer M, Goslee KM, Brown S (2012). Standard operating procedures for terrestrial carbon measurement: version 2014. Winrock International, Arkansas, USA, pp. 96. [online] URL: http://winrock.org/ wp-content/uploads/2013/08/Winrock_Terrestri
al_Carbon_Field_SOP_Manual_Feb2018.pdf Walkley A, Black IA (1934). An examination of the Degtjareff method for determining soil organic matter and a proposed modification of the chromic acid titration method. Soil Science 37 (1): 29-38. - doi: 10.1097/00010694-19340100 $0-00003$

\section{Supplementary Material}

Tab. S1 - Living trees measurement of different girth classes for mixed cropping and forest swamp plots.
Tab. S2 - Peat profile description for mixed cropping and forest swamp plots.

Fig. S1 - Layout of a sampling plot design and a cluster of plots that was used in this study.

Fig. S2 - Rainfall and air temperature patterns in the study site from July 2018 to August 2019.

Fig. S3 - Water filled pore space at the study site (August 2018 - August 2019).

Link:Vijayanathan_3700@supploo1.pdf 